\title{
17. SYNTHESIS OF OLIGOCENE TO QUATERNARY BIOSTRATIGRAPHY OF THE PHILIPPINE SEA, DEEP SEA DRILLING PROJECT LEG 59
}

\author{
Erlend Martini, Geologisch-Paläontologisches Institut der Universität, Frankfurt am Main, Germany, \\ Mary E. Heiman, ${ }^{1}$ Stratigraphy Laboratory, Mobil Oil Company, Dallas, Texas \\ and \\ Fritz Theyer, Hawaii Institute of Geophysics, University of Hawaii at Manoa, Honolulu, Hawaii
}

\section{INTRODUCTION}

During Leg 59 of the Deep Sea Drilling Project, five sites (447-451) were occupied and seven holes drilled between Okinawa and Guam in the Philippine Sea. All sites yielded calcareous nannoplankton, foraminifers, and radiolarians, the various occurrences of which are discussed in detail in this chapter. Ichthyoliths (Dengler et al., 1975) were especially common in the brown clays at Site 447, whereas diatoms and silicoflagellates were found only in part of the Quaternary interval of Holes 449,450 , and 451.

Geographical positions of the DSDP holes drilled during Leg 59 are as follows (see Fig. 1):

1) Holes $447,447 \mathrm{~A} 18^{\circ} 00.88^{\prime} \mathrm{N}, 133^{\circ} 17.37^{\prime} \mathrm{E}$, water depth 6022 meters.

2) Holes $448,448 \mathrm{~A} 16^{\circ} 20.46^{\prime} \mathrm{N}, 134^{\circ} 52.45^{\prime} \mathrm{E}$, water depth 3483 meters.

3) Site $44918^{\circ} 01.84^{\prime} \mathrm{N}, 136^{\circ} 32.19^{\prime} \mathrm{E}$, water depth 4712 meters.

4) Site $45018^{\circ} 00.02^{\prime} \mathrm{N}, 140^{\circ} 47.34^{\prime} \mathrm{E}$, water depth 4707 meters.

5) Site $45118^{\circ} 00.88^{\prime} \mathrm{N}, 143^{\circ} 16.57^{\prime} \mathrm{E}$, water depth 2060 meters.

\section{ZONATIONS, AGES, AND CORRELATION TO STRATOTYPES}

The standard calcareous nannoplankton zonation (Martini, 1971) is used for the Tertiary and Quaternary material discussed in this chapter. Differences between this zonation and that used for Leg 31 (Karig, Ingle, et al., 1975) and Leg 60, which is based mainly on Bukry (1971 and 1973), are discussed in the nannoplankton chapter (Martini, this volume). For the planktonic foraminifers, the numerical system proposed by Banner and Blow (1965) and Blow (1969) is used; this is based on datum planes of selected age-determinant taxa that appear first or, less frequently, last at a zonal boundary, as in the standard nannoplankton zonation. Concerning the radiolarians, the zonation of Nigrini (1971) is applied in the Quaternary, that of Riedel and Sanfilippo (1971) in the Oligocene to Pliocene interval.

Calcareous nannoplankton is the fossil group best represented in the cores recovered. Therefore we cal-

\footnotetext{
${ }^{1}$ Present address: $\mathrm{F}$ and $\mathrm{H}$ Biostratigraphic Associates, 2024 Sheridan, Laramie, Wyoming.
}

culated the accumulation rates and basement ages as well as the time-equivalent spacing (see Tables 1 and 2) using the estimated time relations for the boundaries of the standard calcareous nannoplankton zonation as indicated by Martini (1976). The correlation to stratotypes presented here is also based mainly on calcareous nannoplankton data and on discussions and conclusions of the Sixth Congress of the Regional Committee on Mediterranean Neogene Stratigraphy held in Bratislava, 1975.

On the basis of the calcareous nannoplankton assemblages, the lower Oligocene (or Latdorfian) includes nannoplankton Zones NP 21 and NP 22 (Martini, 1971; Benedek and Müller, 1976), the middle Oligocene (or Rupelian) comprises Zone NP 23 and part of Zone NP 24 (Müller, 1970; Martini, 1971), and the upper Oligocene (or Chattian) includes part of nannoplankton Zone NP 24 and Zone NP 25 (Martini and Müller, 1975). The Paleogene/Neogene boundary is identified at the NP $25 / \mathrm{NN} 1$ boundary of the standard nannoplankton zonation. For the lower Miocene (or Aquitanian and Burdigalian), nannoplankton data are rather sparse but indicate a correlation to the interval of nannoplankton Zones NN 1 to part of Zone NN 4 (Müller, 1974, Bizon and Müller, 1977). The base of the middle Miocene (or Langhian and Serravallian) is in the upper part of nannoplankton Zone NN 4 and the top of the middle Miocene within Zone NN 9 (Martini, 1968, 1971; Müller, 1975). The base of the upper Miocene (or Tortonian and Messinian) is in the upper part of Zone NN 9. Because the lower Pliocene is a transgressive phase following the upper-Miocene salinity crisis in the Mediterranean, there is still some discussion about the exact position of the Miocene/Pliocene boundary in the nannoplankton zonation; however, a position within Zone NN 12 seems most likely (Martini, 1975; D’Onofrio et al., 1975; Cita et al., 1973). Accordingly, the lower Pliocene (or Zanclean) includes part of nannoplankton Zone NN 12 and reaches to Zone NN 15 (Cita and Gartner, 1973). The upper Pliocene (or Piacenzian) contains Zones NN 16 to NN 18 and is considered to terminate with the last occurrences of Discoaster brouweri in the open ocean in low and middle latitudes. Correlations to planktonic foraminiferal zones and radiolarian zones in the present report are based solely on occurrences in Leg 59 material (Table 1); but in some parts of the stratigraphic column, correlations are hampered by the lack of fora- 


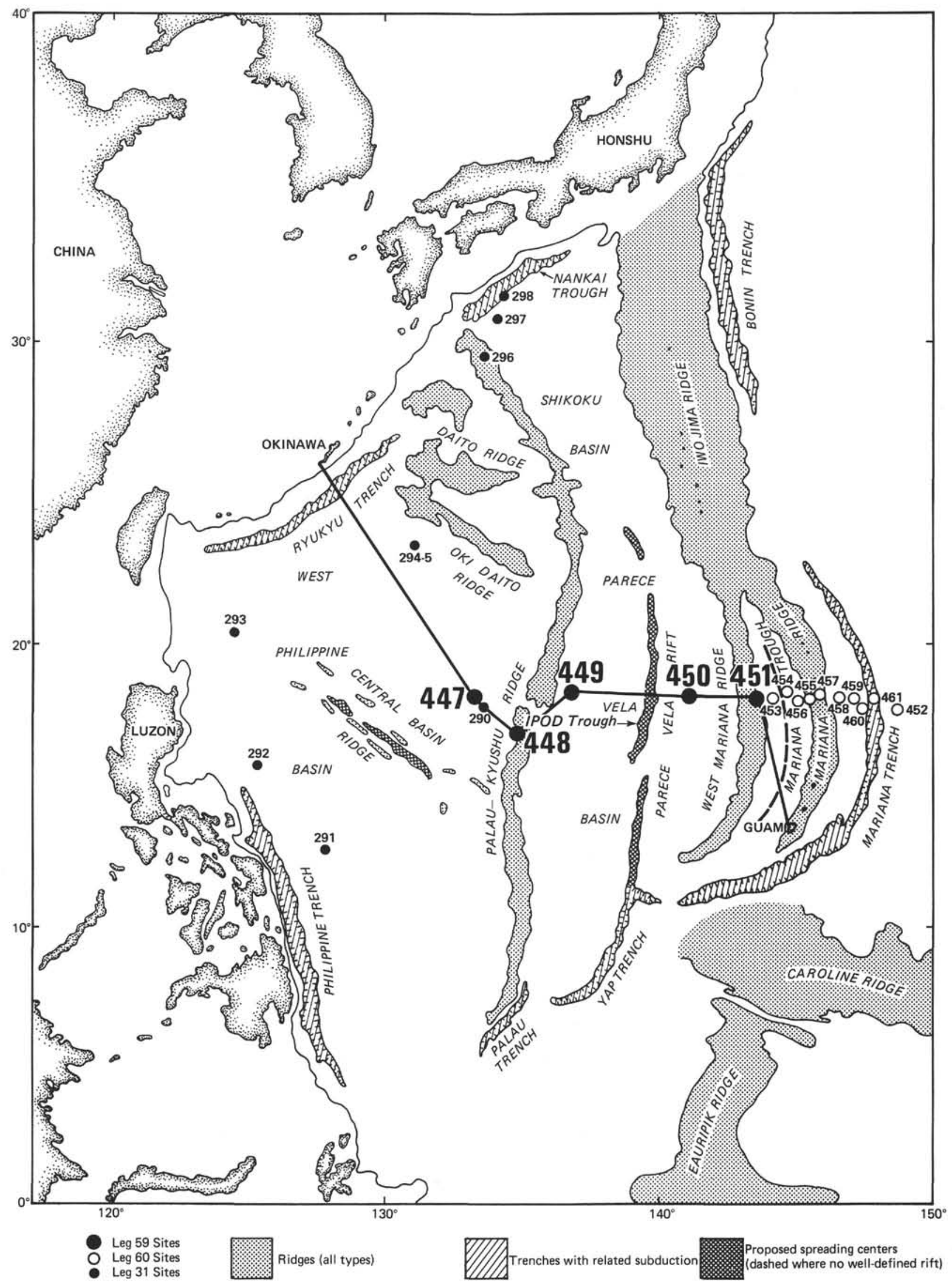

Figure 1. Location of Leg 59 sites. 
Table 1. Correlation between different fossil groups based on Leg 59 material.

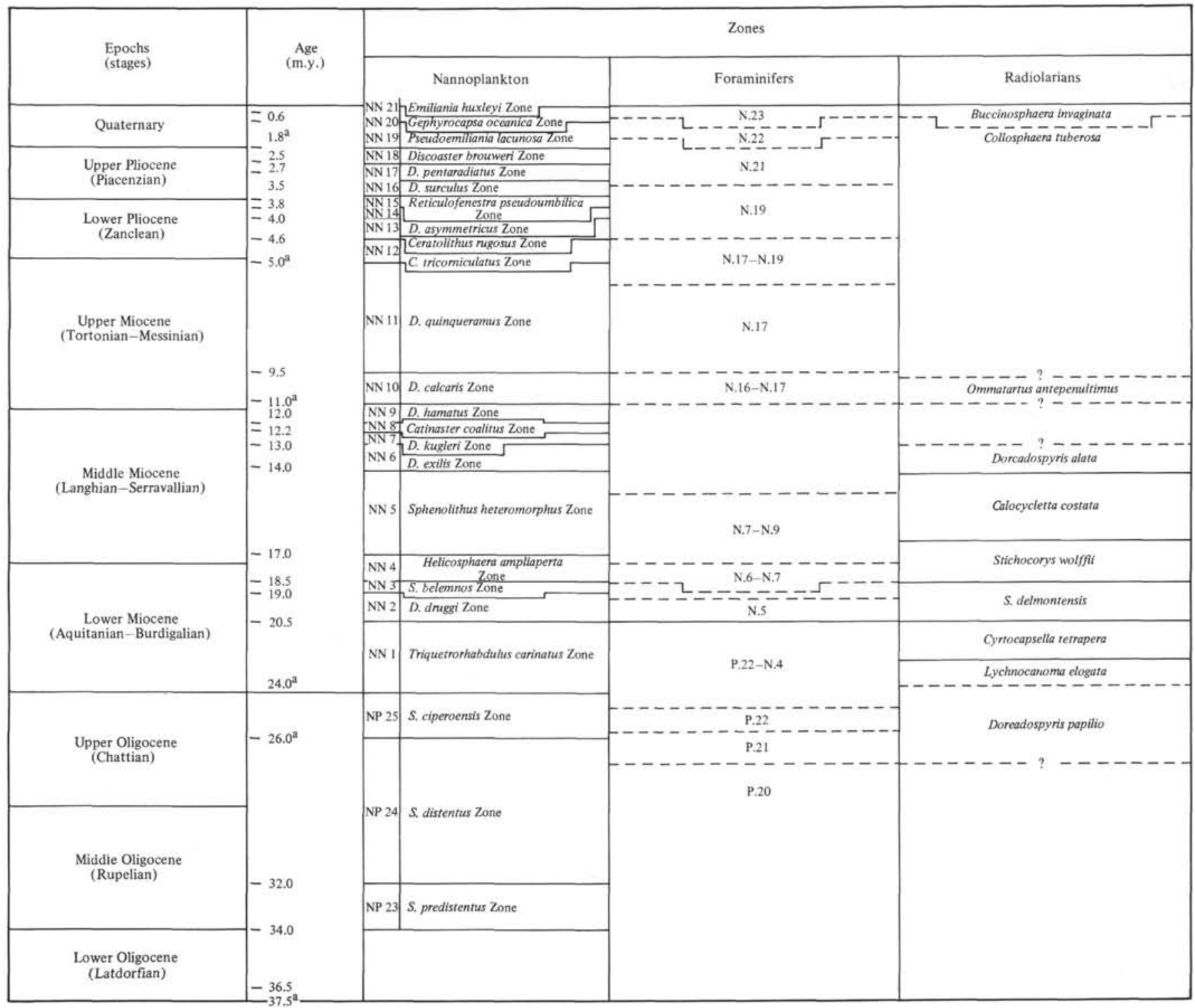

Note: Uncertainties and lack of foraminiferal and radiolarian zones are due to barren intervals.

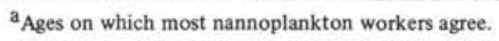

minifers and radiolarians, which is the result of dissolution, as discussed in the following material and indicated by data represented in Tables 1 and 2 .

\section{SEDIMENTS RECOVERED AND PRESENCE OF VARIOUS FOSSIL GROUPS}

In the deep-water Sites 447 (West Philippine Basin), 449, and 450 (Parece Vela Basin) pelagic clays were deposited from the late Oligocene and late Miocene, respectively, with an additional interval of pelagic-clay sedimentation at Site 449 in the late early to early middle Miocene. Below these pelagic clays, sediments deposited include nannofossil oozes and chalk breccias that grade downward into vitric tuffs (Site 450) and basalt sedimentary breccia (Site 447) or are directly underlain by basalt (Site 449). The other two sites are situated on the Palau-Kyushu Ridge (Site 448) and West Mariana Ridge
(Site 451), where, after deposition of large amounts of vitric tuffs and breccias, deposition of nannofossil oozes and chalks or calcareous biogenic oozes took place. These changes can be dated as late Oligocene at Site 448 and late Miocene at Site 451. Fossil occurrences directly relate to sediment types, reflecting water depth and/or extensive input of volcanogenic material, as discussed in the paleoenvironment section.

Calcareous nannoplankton occurs in all holes (Table 2 ), but its presence is dependent on the water depth and also on the amount of volcanogenic material deposited during times of volcanic activity. At Site 447 (on the eastern side of the West Philippine Basin, with a present water depth of 6022 meters) we encountered calcareous nannoplankton only in the lower part of the sedimentary column, which includes poorly preserved species that indicate Oligocene Zones NP 23 (Sphenolithus pre- 
Table 2. Occurrence of different fossil groups in Leg 59 holes.

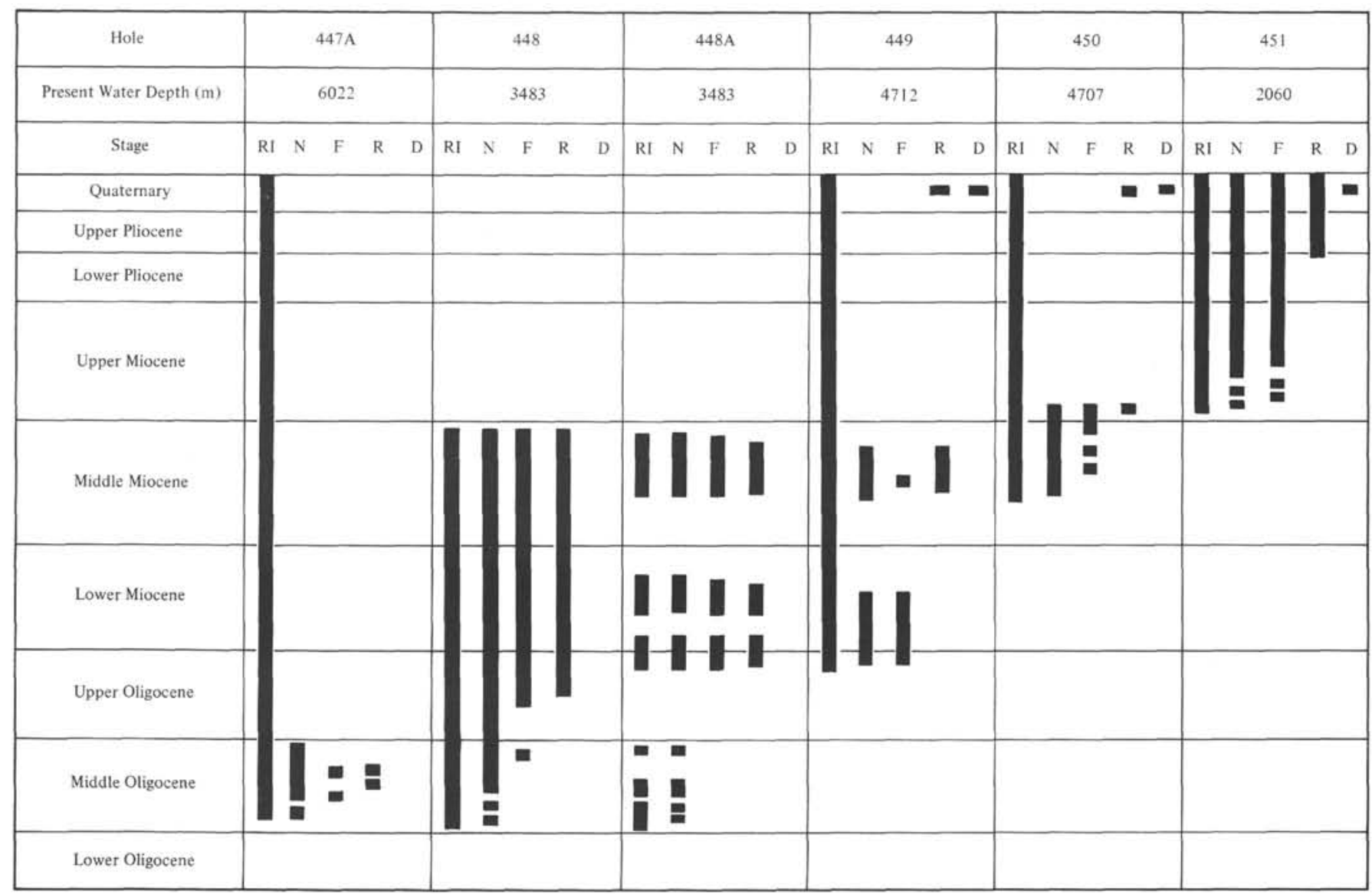

Note: $\mathrm{RI}=$ recovered interval, $\mathrm{N}=$ calcareous nannoplankton, $\mathrm{F}=$ foraminifers, $\mathrm{R}=$ radiolarians, $\mathrm{D}=$ diatoms.

distentus Zone) and NP 24 (S. distentus Zone) together with some specimens probably displaced from lowerOligocene deposits.

In Holes 448 and 448A (situated on the PalauKyushu Ridge in a present water depth of 3483 meters), nannoplankton from Zone NN 9 (Discoaster hamatus Zone) down to Zone NP 23 (S. predistentus Zone) is found in continuous succession in the cores recovered. Preservation is fairly good in the uppermost part (middle Miocene), but below, specimens are slightly etched and discoasters are overgrown by calcite; in the lowest sediment layers as well as in sediments trapped within or between basalt flows, preservation is generally poor. The nearby piston core V34-13 contained calcareous nannoplankton assemblages dominated by discoasters of the early Pliocene and late Miocene, overlain by a thin sediment cover of the late Quaternary. The occurrence of fair numbers of Zygrhablithus bijugatus in Core 16 and below seems to indicate that the water depth at Site 448 during part of the Oligocene was relatively shallow.

Situated in the Parece Vela Basin with a present water depth of 4712 meters and 4707 meters, respectively, Sites 449 and 450 contain calcareous nannoplankton only in part of the middle Miocene (Zones NN 5 through NN 9) and around the Oligocene/Miocene boundary (Zones NP 25 through NN 2). All other inter- vals cored are barren of calcareous nannoplankton. Assemblages recovered in the middle Miocene are poorly preserved with heavy calcite overgrowth in discoasters, especially at Site 449 , but show fairly good preservation at Site 450 (with discoasters only slightly overgrown by calcite, probably because of the high ash content of the sediments). In the lowest part of Hole 450 calcareous nannoplankton is strongly etched and only the more solution-resistant parts are preserved.

At the West Mariana Ridge, Hole 451 was drilled in a water depth of 2060 meters and yielded a complete succession from nannoplankton Zone NN 21 (Emiliania huxleyi Zone) down to the upper Miocene Zone NN 10 (D. calcaris Zone), with nannoplankton fairly well preserved down to Core 20. Below, preservation in the nannoplankton-bearing layers within the volcanogenic sediments is poor.

A similar distributional trend can be observed for the foraminifers (Table 2) which, combined with the nannoplankton data, can be used for determination of the carbonate compensation depth (CCD) for certain intervals in the holes drilled. At Site 447 rare planktonic and benthic foraminifers were found in the middle Oligocene interval. All other samples examined from Hole 447A are barren of foraminifers.

Poorly to moderately well-preserved middle Miocene to upper Oligocene foraminiferal assemblages are pres- 
ent at Site 448 on the Palau-Kyushu Ridge; these assemblages can be placed in Blow's Zones N.9 to P.20 and are the basis for the correlation between the foraminiferal and nannoplankton zones shown in Table 1 . Middle Oligocene samples investigated are either barren or nearly barren of foraminifers.

At Sites 449 and 450 , in the Parece Vela Basin, distribution of foraminifers is again somewhat similar to the nannoplankton distribution in cores recovered. Rare benthic foraminifers, in some samples associated with very rare planktonics, are encountered in part of the middle Miocene and around the Oligocene/Miocene boundary in Hole 449. Rare planktonic foraminifers occur sporadically in the lower part of the upper Miocene and the upper part of the middle Miocene in Hole 450. All samples investigated from other intervals are essentially barren of foraminifers.

Moderately well-preserved planktonic foraminifers are common to abundant at the West Mariana Ridge Site 451 from Core 1 (late Quaternary) through Core 14 (late Miocene). Below this level they occur infrequently because the more abundant volcanogenic sediments often dilute their presence, and preservation is generally poor with increased induration of the sediments.

In the lower part of the sedimentary column of Site 451 , we found larger foraminifers and associated shallow-water fossils. Selected samples from Cores 31, $40,42,46,47,50,69,71$, and 72 were sent to Dr. Beckmann in Zurich for inspection. He reported that the best faunas were recovered from Cores 40,71 , and 72, but that even in these samples only Amphistegina spp. and Ammonia cf. indopacifica (Thalmann) are fairly common. Preservation is usually moderate to poor, and specimens commonly are recrystallized into clear calcite. The most significant genera of larger foraminifers from Site 451 are Lepidocyclina, Miogypsina, Miogypsinoides, and Cycloclypeus; also the group Operculina-Operculinella-Operculinoides is present in most samples. Two specimens of Miogypsinoides from Sample 451-71-1, 0-9 cm seem to be close to $M$. complanata (Schlumberger) and are probably reworked, which limits the value of the larger foraminiferal faunas in determining age. According to Dr. Beckmann (see Site 451 report, this volume), the associations of Cores 71 and 72 would suggest that they are from the middle Miocene (upper Tertiary f). Stratigraphically higher samples, particularly from Core 40 , might be slightly younger, probably from the early part of the late Miocene (upper Tertiary f). The original life habit of the fauna was probably a fairly shallow reef (fore-reef shoal). The associated pelecypod fragments, echinoid spines, and some bryozoans give further support to this assumption. Rare coral fragments may also indicate the vicinity of a reef.

There are fewer siliceous microfossils, which are present to a certain degree in parts of the cored intervals (Table 2) than there are foraminifers. In Hole 447A (at the eastern side of the West Philippine Basin), radiolarians are extremely rare and occur only in the middle Oligocene interval. A fairly good uppermost Oligocene to middle Miocene radiolarian succession occurs in the
Palau-Kyushu Ridge Holes 448 and 448A, although the assemblages never are as diverse and abundant as they are in samples from comparable depths in the Central Pacific. There is evidence in virtually every sample that strong dissolution of silica prevailed and individuals of fragile species are often absent or fragmentary. The lower part (middle to lower upper Oligocene) in both holes is barren of radiolarians. At the Parece Vela Basin Sites 449 and 450 meager radiolarian assemblages occur in the Pleistocene. Farther down a sparse radiolarian association is present in the lower upper Miocene of Hole 450, and a well-preserved and abundant radiolarian fauna occurs in part of the middle Miocene of Hole 449. The other cored intervals are barren of radiolarians. Cores 1 through 3 of Hole 451 on the West Mariana Ridge contain radiolarians in sufficient numbers to study. In Cores 4,10 , and 14 traces of this group are present, whereas all other cores appear to lack radiolarians.

Diatom assemblages associated with rare silicoflagellates, sponge spicules, and very rare endoskeletal dinoflagellates are found in the Quaternary of Sites 449 and 450 , both of which have a water depth of more than 4700 meters. The diatom assemblages are dominated by Ethmodiscus specimens, especially at Site 449, where in Sample 449-2-1, 42-43 cm, Ethmodiscus specimens are concentrated, probably because of dissolution of other species to an Ethmodiscus ooze. At Site 451, with a water depth of 2060 meters, diatoms and silicoflagellates are also present in Pleistocene and Pliocene sediments but without concentration of Ethmodiscus valves found in the deep-water Sites 449 and 450 .

We found ichthyoliths in the upper part of the pelagic clay unit of the deep-water Site 447 . They were also noted in the pelagic clay units in the upper parts of Holes 449 and 450 but were not specifically investigated.

\section{ACCUMULATION RATES AND BASEMENT AGES}

Accumulation rates are described in detail in the site chapters and will be discussed here only in relation to type of sedimentation and fossil occurrences.

Typical pelagic clays were recovered at Sites 447,449 , and 450. Accumulation rates deduced from fish-teeth and rare radiolarian occurrences indicate deposition of about 1.3 meters per m.y. for the upper Oligocene to Quaternary interval at Site 447,4 meters per m.y. for the upper upper Oligocene to Quaternary interval at Site 449 , and about 3 meters per m.y. for the upper Miocene to Quaternary interval at Site 450 . The relatively high accumulation rate at Site 449 is caused by intercalated biogenic oozes and volcanic material that could not be separated for a detailed determination of accumulation rates.

Calcareous biogenic oozes and chalks generally show higher accumulation rates, with the exception of a solution-affected, discoaster-dominated nannofossil ooze of the middle Miocene at Site 448, where depositional rates approached 1 meter per m.y. Farther down in the lower Miocene and upper Oligocene, however, nannofossil oozes and chalks show accumulation values of about 10 to 15 meters per m.y. 
Volcanogenic sediments dominate at most sites and in most levels contain minor amounts of biogenic material. At Site $\mathbf{4 4 7}$ fossil data were insufficient for determination of the accumulation rates. In the vitric-tuff units of Site 448 on the Palau-Kyushu Ridge, average sediment accumulation rates exceeded 30 meters per m.y. in the middle to upper Oligocene. At the Parece Vela Basin Site 450 accumulation rates for the lower to middle Miocene tuffaceous and ash-bearing sediments amounted to 54 meters per m.y. and were especially high at the West Mariana Ridge Site 451, where in the lower upper Miocene the very rapid accumulation of volcanogenic material exceeded 390 meters per m.y. (by extrapolation).

We reached basement at the first three sites. The presence of calcareous nannoplankton Zone NP 23 (Sphenolithus predistentus Zone) in sediments at the contact indicates that basement at Sites 447 and 448 is of the middle Oligocene (between 32 and 34 m.y.). At Site 449, in the Parece Vela Basin, basement was reached at 111.0 meters and is overlain by upper-Oligocene (between 24 and 26 m.y.) nannofossil ooze belonging to Zone NP 25 (Sphenolithus ciperoensis Zone). At the other Parece Vela Basin site (450) basement was not reached, and drilling was terminated in an intrusive basalt within middle Miocene vitric tuffs-including minor amounts of calcareous constituents, indicating nannoplankton Zone NN 5 (S. heteromorphus Zone) with an extrapolated age of about $17 \mathrm{~m} . \mathrm{y}$. at the contact. Neither was basement reached at the West Mariana Ridge Site 451, where the oldest sediments cored are approximately as old as $11 \mathrm{~m} . \mathrm{y}$., as indicated by the presence of the basal part of nannoplankton Zone NN 10 (Discoaster calcaris Zone) in Core 85 some 150 meters above the terminal depth of 930.5 meters.

\section{PALEOENVIRONMENT}

Poorly preserved calcareous nannoplankton and rare foraminifers from the West Philippine Basin Site 447 suggest a deposition of sediments near the CCD during the middle Oligocene (Cores 5 to 12). The CCD in the Philippine Sea today lies somewhere between 4000 and 4500 meters, according to Ujiie (1975). From the upper Oligocene (Cores 4 up to 1), sediments are barren of calcareous and siliceous microfossils, suggesting deposition took place possibly near the present-day water depth of about 6000 meters-certainly below the CCD.

At the Palau-Kyushu Ridge Site 448, fossil groups from the interval sampled suggest that a tropical climate prevailed in the area throughout the middle Oligocene to middle Miocene. The lower part of the sediment column of Hole 448 (approximately below Core 13) possibly was deposited in a middle or upper bathyal environment, according to the benthic foraminifers and nannofossils that are present in Cores 14 through 19 . Nannoplankton data also seem to support this hypothesis because Zygrhablithus bijugatus, typically a neritic species, occurs in fair numbers in these cores (Martini, this volume). The middle part of the column (Cores 7 to 12 of Hole 448) is marked by an increase in arenaceous benthic foraminifers, which, together with the generally poor preservation of calcareous fossils, suggests that this part was deposited near the foraminiferal lysocline. The upper part of the column (Cores 1 to 6) contains more calcareous foraminifers, but the solution-affected, discoaster-dominated nannoplankton assemblages in Core 1 , as well as a very low accumulation rate, suggest continued deep-water conditions. The foraminiferal assemblage indicates a deep bathyal to abyssal depositional environment.

The sediment columns of the Parece Vela Basin Site 449 show a trend from shallower to deeper depositional environment. Sediments above the basalt at this site contain a relatively diverse planktonic foraminiferal assemblage and fairly well-preserved calcareous nannofossils of both the upper Oligocene and lower Miocene (Core 13), but upward to Core 10 preservation of both fossil groups becomes poor. The sediments sampled in Core 13 through the base of Core 10 were therefore deposited above the CCD, with the shallowest level of the CCD coinciding with the oldest sediment. The upper part of Core 10 as well as Cores 8 and 9 are barren of calcareous and siliceous fossils, suggesting an accumulation of sediments below the CCD during part of the early Miocene. In the middle Miocene (Cores 6 and 7) the CCD was slightly lower, as indicated by the presence of calcareous nannoplankton. Rare arenaceous benthic foraminifers and abundant, well-preserved radiolarians are also present. Above Core 6, sediments are barren of calcareous and siliceous microfossils, with the exception of an interval in the late Quaternary that contains radiolarians, diatoms, and sponge spicules, indicating that the interval from the upper middle Miocene to the Holocene was deposited below the CCD.

At Parece Vela Basin Site 450, calcareous nannofossils are continuously present from the middle of Core 35 up to Core 6, with planktonic foraminifers occurring in most samples from the base of Core 6 through Core 17, but only rarely and sporadically below Core 17 . These data suggest that the lower portion of the sediment column (Cores 7 and below) was deposited somewhat above the CCD during the middle Miocene. The preservation of calcareous microfossils in the interval represented by Cores 6 through 33 may, however, be due to rapid burial (as reflected in the high ash content of these sediments). The absence of nannofossils in the basal sediments (lower portion of Core 35 and Core 36) is probably caused by hydrothermal alteration of the sediments above the intrusive basalt. Cores 1 through 5 lack calcareous fossils and were deposited below the CCD. A limited occurrence of calcareous nannoplankton, rare benthic foraminifers, and radiolarians in parts of Cores 4 and 5 may represent displaced material from nannoplankton Zones NN 9 and NN 10 within the unfossiliferous pelagic clay.

At the West Mariana Ridge Site 451, rare, poorly preserved calcareous fossils were noted from near the bottom of the hole up to Core 20 within the early upperMiocene volcanogenic sediments. Larger foraminifers and associated shallow-water fossils were found in the lower part (from Core 31 downward) of the sediment column. As discussed earlier, the original life habit of 
this fauna was probably a fore-reef shoal; rare coral fragments also seem to indicate the vicinity of a reef in the early stages of deposition. Cores 11 to 13 and 15 to 19 are either barren or there was no recovery. In Core 14 and above Core 11, sediments contain common to abundant moderately well-preserved calcareous nannoplankton and planktonic and benthic foraminifers, suggesting deposition above the CCD from late Miocene through Recent time. The benthic foraminifers indicate deep bathyal to abyssal depths, but above the CCD and the foraminiferal lysocline.

\section{ACKNOWLEDGMENTS}

Thanks are due to the Deutsche Forschungsgemeinschaft for supporting the present study. Miss Anne Hossenfelder helped to assemble the data for Tables 1 and 2 . We are also indebted to Dr. J. P. Beckmann (Geologisches Institut der ETH, Zürich) for supplying us with information on the larger foraminifers and associated shallow-water fossils found in the lower part of Hole 451.

\section{REFERENCES}

Banner, F. T., and Blow, W. H., 1965. Progress in the planktonic foraminiferal biostratigraphy of the Neogene. Nature, 208: 1164-1166.

Benedek, P. N. V., and Müller, C., 1976. Die Grenze Unter-/MittelOligozän am Doberg bei Bünde/Westfalen. I. Phyto- und Nannoplankton. Neues Jahrb. Geol. Palaeontol., Monatsh. 1976, 129-144.

Bizon, G., and Müller, C., 1977. Remarks on some biostratigraphic problems in the Mediterranean Neogene. Symp. Int. Struct. Hist. Mediterran. Basins, Split 1976, 381-390.

Blow, W. H., 1969. Late middle Eocene to Recent planktonic foraminiferal biostratigraphy. Proc. First Internat. Conf. Plankt. Microfossils, Geneva, 1967, Vol. 1:199-422.

Bukry, D., 1971. Coccolith stratigraphy Leg 6, Deep Sea Drilling Project. In Fisher, A. G., Heezen, B. C., et al., Init. Repts. DSDP, 6: Washington (U.S. Govt. Printing Office), 965-1004. 1973. Low-latitude coccolith biostratigraphic zonation. In Edgar, N. T., Saunders, J. B., et al., Init. Repts. DSDP, 15: Washington (U.S. Govt. Printing Office), 685-703.

Cita, M. B., and Gartner, S., 1973. Studi sul Pliocene e sugli strati di passaggio dal Miocene al Pliocene. IV. The stratotype Zanclean foraminiferal and nannofossil biostratigraphy. Riv. Ital. Paleontol. Stratigr., 79:503-558.

Cita, M. B., Stradner, H., and Ciaranfi, N., 1973. Studi sul Pliocene e sugli strati di passaggio dal Miocene al Pliocene. III. Biostrati- graphical investigations on the Messinian stratotype and on the overlying "Trubi" Formation. Riv. Ital. Paleontol. Stratigr., 79:393-446.

Dengler, A. T., Doyle, P. S., and Riedel, W. R., 1975. Ichthyoliths in some samples from the Philippine Sea, Deep Sea Drilling Project Leg 31. In Karig, D. E., Ingle, J. C., Jr., et al., Init. Repts. DSDP, 31: Washington (U.S. Govt. Printing Office), 821-833

D’Onofrio, S., Gianelli, L., Iaccarino, S., et at., 1975. Planktonic foraminifers of the upper Miocene from some Italian sections and the problem of the lower boundary of the Messinian. Boll. Soc. Paleontol. Ital., 14:177-196.

Karig, D. E., Ingle, J. C., Jr., et al., 1975. Init. Repts. DSDP, 31: Washington (U.S. Govt. Printing Office).

Martini, E., 1968. Calcareous nannoplankton from the type Langhian. Giorn. Geol., 35:163-172.

1971. Standard Tertiary and Quaternary calcareous nannoplankton zonation. Proc. Second Plankt. Conf., Roma 1970, Vol. 2:739-785.

, 1975. Calcareous nannoplankton from the type Tortonian (upper Miocene). Proc. Sixth Congr. Mediterran. Neogene Strat., Vol. 1:53-56.

, 1976. Cretaceous to Recent calcareous nannoplankton from the Central Pacific Ocean (DSDP Leg 33). In Schlanger, S. O., Jackson, E. D., et al., Init. Repts. DSDP, 33: Washington (U.S. Govt. Printing Office), 383-423.

Martini, E., and Müller, C., 1975. Calcareous nannoplankton from the type Chattian (Upper Oligocene). Proc. Sixth Congr. Mediterran. Neogene Strat., Vol. 1:37-41.

Müller, C., 1970. Nannoplankton aus dem Mittel-Oligozän von Norddeutschland und Belgien. Neues Jahrb. Geol. Palaeontol., Abh., 135:82-101

Müller, C., 1974. Calcareous nannoplankton from mid-Tertiary stratotypes. Mém. Bur. Rech. Géol. Minières., 78:427-432.

1975. Calcareous nannoplankton from the type Serravallian. Proc. Sixth Congr. Mediterran. Neogene Strat., Vol. 1:49-52.

Nigrini, C. A., 1971. Radiolarian zones in the Quaternary of the equatorial Pacific Ocean. In Funnel, B. M., and Riedel, W. R. (Eds.), The Micropalaeontology of Oceans: Cambridge, England (Cambridge University Press), pp. 443-461.

Riedel, W. R., and Sanfilippo, A., 1971. Cenozoic radiolaria from the western tropical Pacific. In Winterer, E. L., Riedel, W. R., et al., Init. Repts. DSDP, 7, Pt. 2: Washington (U.S. Govt. Printing Office), $1529-1672$.

Ujiie, H., 1975. Planktonic foraminiferal biostratigraphy in the Western Philippine Sea, Leg 31 of DSDP. In Karig, D. E., Ingle, J. C., Jr., et al., Init. Repts. DSDP, 31: (U.S. Govt. Printing Office), 677-691. 